\title{
ЗАХВОРЮВАНІСТЬ ТКАНИН ПАРОДОНТА ВАГІТНИХ, МЕХАНІЗМИ ВИНИКНЕННЯ ТА РОЗВИТКУ (ОГЛЯД ЛІТЕРАТУРИ)
}

Вищий державний навчальний заклад України «Українська медична стоматологічна академія», м. Полтава

Резюме. У статті представлений аналіз джерел літератури щодо високої поширеності та інтенсивності хвороб пародонта у вагітних, поліетіологічності їх виникнення, складний механізм розвитку. Але ці питання мають дискусійний характер, не завжди фактично аргументовані, що, у свою чергу, зумовлює низький рівень первинної профілактики змін у тканинах пародонта та недостатню медичну ефективність лікувальних заходів

Проблема захворювання тканин пародонта у вагітних продовжує залишатись актуальною та перебуває на етапі вивчення серед питань практичної та теоретичної стоматології, становлячи значну соціальну та економічну проблему [9, 10, 22, 24].

Відомо, що вагітні є групою ризику за розвитком стоматологічних захворювань [9, 12, 22, 25]. Особливий інтерес викликають дані про стан тканин пародонта під час вагітності. Відсутність хронічних вогнищ інфекції, у тому числі і в зубощелепному апараті жінки, $є$ фундаментальною основою здоров'я майбутньої дитини. Але, на жаль, клінічні прояви патологічних змін тканин пародонта у вагітних різні автори діагностують у 60-80 \% [25]. Найчастіше хвороби тканин пародонта у вагітних проходять у формі катарального та гіпертрофічного гінгівіту $[9,12]$, їх часто ідентифікують як окрему нозологічну форму та об'єднують під назвою “гінгівіти вагітних", які становлять $46,66 \%$ [10, 25].

Так, згідно з даними Г.С. Чучмая [25], зміни стану тканин пародонта під час вагітності реєстрували у 47 \% жінок, при цьому спостерігали як загострення хронічного запалення, так і появу запального процесу в яснах безпосередньо під час вагітності. Вже в першому триместрі (8-12-й тиждень вагітності) діагностують прояви перших клінічніх ознак змін тканин пародонта. Характерно, що кількість катарального гінгівіту та пародонтиту з віком вагітних збільшується, а гіпертрофічного гінгівіту зменшується [25].

Наявність гіпертрофічного гінгівіту в 3,6 \% жінок під час вагітності встановила В.Л. Губаревская [4]. Автор відмітила підвищення розповсюдженості “пародонтопатій” у вагітних до 47,6\%, тоді як у невагітних жінок до $28 \%$ та зазначила, що запальні зміни тканин пародонта вперше виникають у жінок під час вагітності у 62,4 \%, а загострення раніше наявних запальних змін спостерігала в 7,6 \%. При цьому, як зазначає автор, рівень гігієни, ступінь санаційної роботи лікарівстоматологів, наявність зубних відкладень не впливають на частоту виникнення "пародонтопатій”, а знаходять своє відображення в частоті загострень хронічних процесів [4]. у стоматолога, терапевта та гінеколога щодо загального рівня здоров'я, стоматологічного, психологічного статусу.

Ключові слова: вагітність, хвороби пародонта, пародонтопатогени, стоматологічний статус, психоемоційний статус.

Наступними дослідженнями підтверджено думку В.Л. Губаревської. За даними Ю.Г. Чумакової стало відомо, що клінічний перебіг гінгівітів тісно пов'язаний з перебігом вагітності [24]. Згідно $з$ даними Гогилашвили Кетеван, розповсюдженість запалення ясен у жінок під час вагітності знаходиться в межах від $30 \%$ до $75 \%$. Автор також відмічає превалювання загостреного перебігу запалення: кровоточивість ясен, підвищення виділення ясенної рідини, набряк, підвищення глибини кишень при пародонтиті. У відповідь на хронічний подразник спостерігають епуліс (10\%) - виявлені зміни мають місце $з$ другого місяця гестації та досягають максимуму до восьмого. Підвищення концентрації гормонів підсилює синтез гіалуронової кислоти і комплексів глікозаміногліканів, що осмотично індукує набряк і гіпертрофію ясен - клінічно спостерігаємо тяжку форму перебігу запалення [3]. Автори навіть вважають, що неоваскуляризація ясен відображує стан матки під час вагітності [3].

Згідно з даними літератури, етіологічні фактори запальних захворювань пародонта умовно поділяють на місцеві та загальні, що тісно взаємозв'язані не тільки між собою, а також із загальним станом організму. До останніх відносять зміни ендокринної, вегетативної нервової, імунної систем, судинну патологію [5, 25]. Крім цього, розвиток змін тканин пародонта вагітних пов'язують із наявністю екстрагенітальної патології та ускладненим перебігом вагітності $[8,33]$.

Впливове значення на пародонтологічний статус жінки має іiі вік, кількість та перебіг теперішньої вагітності, післяпологовий період [1, 4, $12,15,24,25]$.

Так, при ускладненому перебігув першовагітних І.В. Сидоренко [17] відзначала 31,3\% захворювань пародонта, а в повторновагітних 68,7 \%. Слід відзначити, що найчастіше у вагітних траплявся ХКГ $[17,24]$.

Необхідно відзначити особливу роль мікробного фактору в розвитку гінгівіту та пародонтиту у вагітних та пряму залежність між виникненням запальних захворювань та гігієнічним станом порожнини рота, у зв'язку з чим підвищується 
інтенсивність стоматологічних захворювань [10, $19,22]$. У жінок за відсутності лікування карієсу частота гінгівітів становить $43,78 \%$, а при проведенні санації порожнини рота - 28 \% [24].

Стосовно запальних захворювань пародонта в джерелах літератури існують дві точки зору [30, 34]. "Неспецифічна гіпотеза зубного нальоту” знаходить зв'язок між рівнем гігієни порожнини рота та станом резистентності тканин пародонта.

“Специфічна гіпотеза зубного нальоту” з'явилась пізніше. Остання стверджує, що важливу роль у деструкції тканин пародонта відіграють Porphyromonas gingivalis, Prevotella (Bacteroides) intermedius i Actinobacillus Actinomycetemcomitans та ін. [29, 34].

Отже, мікробний фактор у розвитку запальних змін у тканинах пародонта в джерелах літератури та наукових дослідженнях на сьогодні $\epsilon$ вивченим та доведеним, але все ж залишається дискусійним щодо його головної ролі при виявленні даних змін у вагітних.

Вагітність є фізіологічним процесом, який супроводжується перебудовою багатьох видів обміну, що, у свою чергу, призводить до змін таких середовищ організму, як слина та кров [5].

Чумакова Ю.Г. (1996), вивчаючи стан слинних залоз під час вагітності, встановила, що порушення їх функції $є$ однією $з$ можливих причин розвитку змін у тканинах пародонта [24].

Вплив на гомеостаз порожнини рота з боку організму через функцію слиновиділення є принципово важливою. Встановлено, що під час вагітності неорганічна і білкова складова слини значно зменшується, знижуючи буферну ємність слини (Лейни/Lain і Пенихакенен/Pienihakkienen) [1].

Вітчизняними лабораторними дослідженнями встановлено, що у вагітних спостерігається зниження pH ротової рідини з подальшим збільшенням в'язкості слини та зниженням швидкості салівації ротової рідини, тобто виявлено зниження функціональної активності слинних залоз [2, 24], що призводить до порушення самоочищення порожнини рота, погіршення гігієнічного стану ротової порожнини. Дане питання $є$ дослідженим в джерелах літератури та доведеним у наукових працях, тому його неодмінного потрібно враховувати під час проведення лікувально-профілактичних засобів у вагітних.

Наступною важливою, можливо і домінуючою, думкою щодо етіологічного фактора $є$ та, що зміни в яснах виникають на тлі зміненого гормонального статуса [3, 4, 22] при вагітності. Згідно 3 даними літератури рівень взаємодії статевих гормонів із клітинними рецепторами різний та залежить від генотипу [22]. Так, Гогилашвіллі та співавтори вважають, що статеві гормони самі по собі не викликають хвороби пародонта і слизової оболонки порожнини рота, але вони можуть змінювати реакцію тканин на мікроорганізми і тим самим побічно сприяти розвитку патологічних процесів [3].

Наступним, не менш цікавим, є ствердження іноземних учених, що домінуючим естрогеном вважається естрадіол, який контролює репродуктивну функцію, диференціацію тканин пародонта (Холлин/Hollin, 1997; Мариотт/Mariott, 1994), а в порожнині рота виявлені естрогенні рецептори типу ER- $\beta$ на слизовій, в епітеліальних клітинах, які і регулюють дозрівання епітелію (Лэйни/Lain і спіавт., 1993) [3].

До кінця I триместру між організмом матері та плода встановлюється складний обмін гормонів. Різка зміна рівня гормонів знаходить своє відображення в порожнині рота, що обгрунтоване наявністю високоспецифічних естрогенних рецепторів у культурі кісткової тканини [22], у тканинах маргінального пародонта, у дрібних судинах [22], або ж впливом статевих гормонів на стан ясен через імунну систему, в якій також відбуваються зміни під час всього гестаційного періоду.

Іноземні вчені стверджують, що виявлені стероїдні гормони в слині знаходять пряме відображення концентрації вільно циркулюючих (не зв'язаних 3 протеїнами) гормонів у крові (Хофман Hofman, 2001). Іншими дослідженнями встановлено, що гормони через ендотелій і гландулярний епітелій потрапляють у слину (Греши/ Groshi,2009) і виконують роль важливого клінічного маркера, наприклад, кортизолу (з метою виявлення гіперсекреції внутрішнього кортизолу), естрадіолу Е2, що запобігає недоношеності (тест затверджено FDA), прогестерону (Вириндж/ Viring, 1986; Тивис/Tivis і співав., 2005) [3].

Відомо, що за механізмом впливу на організм естроген та прогестерон $є$ антагоністами. Так, В.В. Поворознюк та співавт. [13] підтверджують значний вплив статевих гормонів на метаболізм кісткової тканини опорного скелета та коміркового відростка щелеп, проліферацію фібробластів ясен і дозрівання сполучної тканини.

Закордонні вчені дійшли висновку, що рівень естрогенів та прогестерону в яснах впливає на судинну проникність та ексудацію, що призводить до підсилення синтезу простогландину Е2 [36], сприяє зниженню кератинізації та клітинної регенерації. Прогестерон сприяє підтримці запальних процесів, запобігає розвитку реакції миттєвого типу (гостре запалення), але допускає розвиток хронічного запалення в яснах. Крім цього відомо, що останній стимулює синтез медіаторів запалення, простагландину PG2, тим самим збільшуючи концентрацію поліморфноядерних лейкоцитів в ясенній борозні. Він також на 50 \% зменшує синтез інтерлейкіну-6, що знижує резистентність ясен до бактеріальних продуктів [3].

Одним із розповсюджених захворювань, що ускладнюють перебіг вагітності та можуть спричинити зміни ясен та слизової оболонки порожнини рота у вагітних, є залізодефіцитна анемія (ЗДА), при цьому страждає білковий та мінеральний обміни. Вітчизняними дослідженнями встановлено, що клінічно виражена ЗДА має місце у 53,4 \% юних вагітних в віці 14-18 років при превалюванні легкого іiі ступеня (95,2% спосте- 
режень), анемія II ступеня діагностована лише в 4,8 \% пацієнток [26].

У вітчизняній та закордонній літературі $\epsilon$ лише деякі дані щодо змін у ротовій порожнині при залізодефіцитних станах у вагітних $[5,19]$. Практично у кожної вагітної в третьому триместрі розвивається прихований дефіцит заліза, на тлі якого у 30-40 \% розвивається ЗДА [26]. Згідно 3 даними Рудника В.Т. [16] зміни гемограми та показників метаболізму заліза наростають відповідно до ступеня дефіциту заліза. Встановлено, що показники сироваткового еритропоетину значно відрізнялися при тому ж ступені анемії, що залежить від абсолютних показників гемоглобіну i гематокриту. Саме тому вивчення адекватності продукції сироваткового еритропоетину, зниження показників ростка червоної крові, коефіцієнта насичення трансферину залізом, підвищення загальної залізозв'язуючої здатності сироватки крові патогенетичних механізмів виникнення анемії $\epsilon$ доцільним та виправданим [16].

У сучасних літературних дослідженнях клінічно доведено поєднання у вагітних з ЗДА хвороб пародонта і хвороб слизової оболонки порожнини рота (хейліти, глосити). Крім цього, встановлено, що в цей період в організмі жінки формуються порушення мікроекології різних біотопів рота і виявлено підвищений вміст субпопуляцій лімфоцитів із ранніми (СД25+) та пізніми (HLA-DR+) маркерами активації, дисбаланс ЦІК у бік переважання їх патогенних фракцій, підвищення рівня прозапальних цитокінів ФНО- $\alpha$, ІЛ$\beta$, та ІЛ-6 [21].

Дана проблема має певні труднощі в іiі вивченні, оскільки існують обмеження методів дослідження стану органів та тканин порожнини рота під час вагітності. Тому використання допоміжних методів обстеження залишається актуальними для запобігання захворювання або ранньої діагностики основного діагнозу та його проявів у порожнині рота.

На сьогоднішній день особливої уваги потребує питання щодо причин ураження тканин пародонта за наявної психосоматичної патології. Науковими дослідженнями доведено, що тканини пародонта мають чутливість до стресорних подразників $[8,19]$.

Так, Л.М. Тарасенко [20] вказує на зміни в кістковій тканині, а саме, підсилення демінералізації в умовах хронічної недостатності аліментарних антиоксидантів. Т.М. Стрельченя [19] також відмічає можливий вплив загальних захворювань на виникнення запалення в пародонті через їх дію на процеси пероксидного окиснення ліпідів (ПОЛ). Особлива увага надається механізмам клітинних пошкоджень тканин пародонта при хронічному стресі, а саме ПОЛ.

Дослідженнями I.В. Сидоренко [17] встановлено підсилення процесів ПОЛ у жінок зі звичним невиношуванням вагітності 3 недостатністю функції антиоксидантної системи, оскільки вка- зує на збільшення малонового альдегіду при значному зменшенні відновленого глутатіону.

Проведені наукові дослідження Ю.Г. Чумаковою [24] щодо вивчення стану вільнорадикального окиснення ліпідів і антиоксидантної системи в ротовій рідині визначило, що в жінок із фізіологічним перебігом вагітності спостерігали зниження рівня малонового альдегіду на тлі збільшення активності антиоксидантних ферментів - супероксиддисмутази, каталази, глутатіон-перексидази та глутатіон-редуктази. Зниження накопичених продуктів ПОЛ автор розглядає як результат зміцнення захисних антиоксидантних властивостей ротової рідини у відповідь на зміни в порожнині рота, що викликані вагітністю. Отже, стан показників ПОЛ та системи антиоксидантного захисту у вагітних у ротовій рідині перебуває на етапі дослідження та потребує більш детального вивчення 3 метою розуміння патогенезу запальних змін пародонта у жінок під час вагітності.

Необхідно зазначити, що при запальних та дистрофічних змінах в яснах спостерігаються морфофункціональні зміни, які визначають клінічний перебіг захворювання [14]. Дослідження на сьогодні $є$ актуальними, перебувають на етапах вивчення та $є$ інформативними для діагностики змін у тканинах пародонта. Цитологічні та цитоморфометричні методи дослідження широко використовуються в пародонтології та мають перевагу в їх неінвазивності та інформативності. Останнє є досить важливим для діагностики змін ясен та розуміння їх патогенезу в жінок під час вагітності. Дане питання на сьогодні $\epsilon$ не доведеним та дискусійним у джерелах літератури для даної декретованої групи.

Однією з найбільш важливих та складних у сучасній стоматології залишається проблема патогенезу запальнодеструктивних захворювань тканин пародонта у вагітних [6]. Запалення ясен починається 3 різкої зміни кількості і складу ясенної рідини, порушення цілості зубо-ясенного з'єднання та прогресуючих патологічних змін в яснах. Під дією мікробів, токсинів скупчення лейкоцитів виділяють групу ферментів (протеази, гідролази), які сприяють розвитку запалення. Одночасно, на початку запалення, тучні клітини виділяють медіатори запалення - гістамін, серотонін, простогландини. Комплекс виділених клітинами біологічно активних речовин призводить до порушення мікроциркуляції (уповільненню кровообігу, підвищення проникності капілярної стінки, застійні явища) [11]. Крім цього, відомо, що важливий вплив у розвитку процесу запалення відіграє система імунокомпетентних клітин (ІКК) ясен, до яких відносять Тлімфоцити, клітини системи мононуклеарних фагоцитів, В-лімфоцити, плазматичні клітини. Дисфункція ІКК лежить в основі патогенезу запальних захворювань тканин пародонта [7].

Із прогресуванням запалення та включення в процес періодонтальної зв'язки, кісткової тканини, у зубному нальоті з'являються, а потім прева- 
люють, грамнегативні штами [29]: Porphyromonas gingivalis (P.g.), Actinobacillus actinomycetemcomitans (A.a.), Bacteroides forsythus, Prevotella intermedia, Treponema denticola та ін. [31]. Захисна функція здорових ясен забезпечується системою імунокомпетентних клітин (ІКК), дисфункція яких розглядається як основа запуску та розвитку гінгівіту та пародонтиту. Крім цього хотілося б відмітити, що підвищення вмісту прогестерону в сироватці крові збільшує кількість ясенної рідини, що призводить до зміни стану під'ясенної мікрофлори, збільшуючи рівень виду Porphyromonas. Досить швидкий ріст червоних і помаранчових комплексів Socransky сприяють підвищенню розповсюдженості гінгівіту і більш тяжкому перебігу пародонтиту під час вагітності [3]. Останнім часом у науковій літературі, у тому числі і з пародонтології, спостерігається зацікавленість щодо досліджень молекулярного рівня, а саме більш ранньої системи захисту організму від патогенів - уроджена імунна відповідь [18, 28].

Слід зазначити, що найбільш частою причиною відмінностей у структурі генів $є$ точкові мутації - заміни одиничних нуклеотидів, так званий поліморфізм одиничних нуклеотидів (SNP-singlenucleotide polymorphism), який за рахунок формування специфічних алелів генів має важливий вплив на особливості розвитку захисних реакцій та схильність до ряду захворювань [35]. Так, встановлено, що відправною точкою запуску запалення при гінгівіті $є$ наявність Тоll-подібних (Toll-interleukin-1-receptor) рецепторів у зовнішній мембрані нейтрофілів, макрофагів, кератиноцитів, які забезпечують молекулярну рецепцію патогену із наступним включенням важливих компонентів спадкового імунітету [18]. Тому, на сьогодні, виникає необхідність врахування діагностики поліморфізму генів, а саме Asp299Gly TLR4, з метою прогнозування виникнення та розвитку запальних хвороб тканин пародонта, що важливо для обгрунтування та розробки профілактично-лікувальних заходів у вагітних [27].

Вагітність $є$ фізіологічним станом, який все ж змінює генетично запрограмовану функцію імунної системи у зв'язку із забезпеченням виживання та розвитку плода [23].

У джерелах літератури частіше висвітлюються питання взаємозв'язку психоемоційного стану вагітних $з$ розповсюдженістю та інтенсивністю стоматологічних захворювань [9]. Фізіологічний перебіг вагітності розглядають як стан хронічного стресу, а рівень кортизолу, АКТГ - показники, що відображують вплив стресорних факторів на організм, а склад клітин периферичної крові (нейтрофільоз, лімфопенія, еозинофілія) - свідчать про напруження механізмів гомеостазу, у тому числі системи психічної адаптації в жінок [9].

\section{Висновок}

Аналізуючи наявні наукові роботи, присвячені питанню розповсюдженості та клінічним проявам запальних змін тканин пародонта в жінок під час вагітності, можна дійти висновку, що багато аспектів патогенезу хвороб пародонта вагітних залишаються дискусійними, що суттєво впливає на правильний вектор терапії та ранньої профілактики [32]. Відповідно, підвищити ефективність диспансеризації вагітних можливо, застосовуючи етіологічний та патогенетичний підходи до профілактики та лікування хвороб пародонта, особливо початкових проявів захворювання.

\section{Література}

1. Бахмудов М. В. Гигиеническое состояние полости рта и пораженность кариесом зубов у беременных с первоначально здоровой полости / М.В. Бахмудов, З.Б. Алиева, Б.Р. Бахмудов // Стоматология. - 2010. - № 3. - С. 16-18.

2. Гаджула Н.Г. Індивідуальна профілактика карієсу зубів у жінок у періоди вагітності та лактації: автореф. дис. на здобуття наук. ступеня канд. мед. наук: спец. 14.01.22 "Стоматологія" / Н.Г. Гаджула. - Львів, 2009. - 18 с.

3. Гогилашвили Кетеван. Гингивит беременных/ Кетеван Гогилашвили, Табагуа Гванца, Самхарадзе Софио // DentArt. - 2013. - № 3. - C. 59-64.

4. Губаревская В.Л. Состояние пародонта при изменении баланса половых гормонов: автореф. дисс. на соискание ученой степени кандидата мед.наук.: спец. 14.00.21. “Стоматология" / В.Л. Губаревская. - Л., 1973. - 16 с.

5. Денисенко Л.Н. Влияние железодефицитной анемии на состояние полости рта беременных женщин: автореф. дис. на соискание науч. степени кандидата мед. наук: 14.00.21 “Стоматология"/ Л.Н.Денисенко. Волгоград, 2007. - 24c.

6. Дунязина Т.М. Современные методы диагностики заболеваний пародонта / Дунязина Т.М., Калинина Н М., Никифорова И.Д. - СПб., 2001. - 53 с.

7. Зайратьянц О.В. Роль иммунокомпентентных клеток десны, Toll-like рецепторов и других молекулярных механизмов в патогенезе воспалительно-деструктивных заболеваний пародонта / О.В. Зайратьянц, С.П. Бойкова, В.А. Смольянникова // Пародонтология. - 2007. - № 3 (44). - С. 12-20.

8. Кисельникова Л.П. Стоматологический статус и профилактика стоматологических заболеваний у беременных / Л.П. Кисельникова, Н.С. Попова // Клин. стоматол. - 2011. - № 1. - С. 86-87.

9. Мухаметзянова Э. Х. Критерии оценки психоэмоционального состояния первородящих / Э. Х. Мухаметзянова, О.А. Красноперова, Т.В. Сушенцова // Акушерство и гинекол. -2010 . - № 2. - С. 56-59.

10. Орехова Н.С. Клиника, лечение и профилактика гингивита у беременных / Н.С Орехова, Е.А. Михеева // Стоматология детского возраста и профилактика. 2007. - № 2. - С. 3-6.

11. Перова М.Д. Новый взгляд на развитие и репарацию повреждений тканей пародонта с позиций молекулярной медицины (аналитический обзор). Часть I. Механизмы рецепции патогенов и передачи сигналов о функциональном состоянии тканей / М.Д.Перова, М.Г.Шубич, В.А.Козлов // Стоматология. - 2007. № 3. - C. 76-80.

12. Петрушанко Т.О. Особливості первинної профілактики стоматологічних хвороб вагітних / Т.О. Петрушанко, Л.Й. Островська // Укр. стоматол. альманах. 2010. - № 3. - C. 32-35.

13. Поворознюк В.В. Костная система и заболевания пародонта / В.В. Поворознюк, И.П. Мазур.- К., 2004. $446 \mathrm{c.}$

14. Помойницкий В.Г. Патогенетическое обоснование алгоритма ранней диагностики гингивита / В.Г. Помойницкий, О.Д. Салюк // Вісн. стоматол. - 2005. № 2. - С. 48-51.

15. Поражаемость кариесом зубом кариесом у беременных женщин / [Данилина Т.Ф., Ткаченко Л.В., Касибина А.Ф., Денисенко Л.Н.]. // Актуал. вопр. Экспе- 
рим., клин. и профилакт. стоматол. - Волгоград, 2005. $-163 \mathrm{c}$.

16. Рудник В.Т. Перебіг залізодефіцитної анемії середнього і важкого ступенів у третьому триместрі вагітності / В.T. Рудник // Гал. лікар. вісник. - 2010. - Т. 17, № 4. - С. 9496.

17. Сидоренко І.В. Особливості клінічного перебігу, профілактики та лікування захворювань пародонта у жінок із звичним невиношуванням вагітності: автореф. дис. на здобуття наук. ступеня канд. мед. наук: спец. 14.01.22 "Стоматологія" / І.В. Сидоренко. - Полтава, 1994. - 18 с.

18. Симбирцев А.С. Функциональный полиморфизм генов регуляторных молекул воспаления / А.С. Симбирцев, А.Ю. Громова // Цитокины и воспаление. -2005. - T. 4, № 1. - C. 3-10.

19. Стрельченя Т.Н. Особливості клінічного перебігу, профілактики та лікування генералізованого гінгівіту у жінок, які страждають на залізодефіцитну анемію: дис. ... канд. мед. наук: 14.01.22 / Т.Н. Стрельченя. Полтава, 1999. - 162 с.

20. Тарасенко Л.М. Індивідуальні механізми стресостійкості тканин пародонта / Л.М. Тарасенко // Імплантологія. Пародонтологія. Остеологія. - 2005. - № 2 (2). C. $74-82$.

21. Тимохина Т.А. Клиника, профилактика и лечение заболеваний пародонта и слизистой оболочки полости рта у женщин репродуктивного возраста с железодефицитной анемией: автореф. дис. на здобуття наук. ступеня канд. мед. наук: спец. 14.01.22 "Стоматологія" / Т.А. Тимохина. - К., 2013. - 18 с.

22. Толмачева С.М. Стоматологические заболевания в период беременности и их профилактика / С.М. Толмачева, Л.М. Лукиных. - М.: Мед. книга, 2005. $150 \mathrm{c}$.

23. Фанченко Н.Д. Эндокринология физиологической беременности / Н.Д. Фанченко, Е.В. Екимова // Рос. мед. ж. - 2007. - № 5. - С. 43-46.

24. Чумакова Ю.Г. Обгрунтування принципів профілактики карієсу зубів і захворювань пародонта у жінок у різні строки вагітності: автореф. дис. на здобуття наук. ступеня канд. мед. наук: спец. 14.01.22 "Стоматологія" / Ю.Г. Чумакова. - К., 1996. - 22 с.
25. Чучмай Г.С. Стоматологічні захворювання у вагітних / Г.С. Чучмай, Н.І. Смоляр. - К.: Здоров'я, 1991. - 104 с.

26. Шехтман М.М. Железодефицитная анемия и беременность / М.М. Шехтман // Гинекология. - 2004. - № 4. C. $204-210$

27. Островська Л.Й. Поліморфізм Asp299Gly гена Tollподібного рецептора 4 в генезі змін ясен у вагітних / Л.Й. Островська, Т.О. Петрушанко, І.П. Кайдашев // Укр. стоматол.альманах. - 2009. - № 6. - С. 17-21.

28. Association between the Asp299Gly polymorphisms in the Toll-like receptor 4 and premature births in the Finnish population / E. Lorenz, M. Hallmam, R. Marttila [et al.] // Pediatr. Res. - 2002. - Vol. 52. - P. 373-376.

29. Bainbridge B.W. Porphyromonas gingivalis lipopolysaccharide: an unusual pattern recognition receptor ligand for the innate host defense system / B.W. Bainbridge, R.P. Darveau // Acta Odontol Scand. - 2001. - № 59. - P. 131-138.

30. Drizhal I. Микробный дентальный налет / I. Drizhal // Новое в стоматол. - 2001. - № 8. - С. 19-24.

31. Jassens S. Role of Toll-like receptors in pathogen recognition / S. Jassens, R. Beyaer // Clin. Microbiol. Rev. 2003. - Vol. 16. - P. 637-646.

32. Laine M.A. Effect of pregnancy on periodontal and dental health / M.A. Laine // Acta Odontol. Scand. - 2002 Oct. Vol. 60, № 5. - P. 257-264.

33. Lopez N. Связаны ли инфекции тканей пародонта с повышенным риском неблагоприятного исхода беременности? / N. Lopez // Dental Tribune. - 2006. - Vol. 5, № 3. - P. 18-20.

34. Porphyromonas gingivalis Lipopolysaccharide Contains Multiple Lipid A Species That Functionally Interact with Both Toll-Like Receptors 2 and 4 / R.P. Darveau, T.T. Pham, K. Lemley [et al.] // Infect and immun. 2004. - Vol. 72. - P. 5041-5051.

35. Sandor F. Toll-like receptors. Biological significance and impact for human medicine / F. Sandor, M. Buc // Folia Biol. ( Praha). - 2005. - Vol. 51. - P. 198-203.

36. The effects of periodontal therapy on intracrevicular prostaglandin E2 concentration and clinical parameters in pregnancy / F. Yalcin, C. Basegmez, G. Isik, F. Yalcin // J. Periodontal. - 2002. - Vol. 73 (2). - P. 177-182.

\section{ЗАБОЛЕВАЕМОСТЬ ТКАНЕЙ ПАРОДОНТА БЕРЕМЕННЫХ, МЕХАНИЗМЫ ИХ ВОЗНИКНОВЕНИЯ И РАЗВИТИЯ (ОБЗОР ЛИТЕРАТУРЫ)}

\section{Л.И. Островская}

Резюме. В статье представлен анализ литературных источников относительно высокой распространенности и интенсивности заболеваний пародонта у беременных, полиэтиологичности их возникновения, сложный механизм развития. Но эти вопросы имеют дискуссионный характер, не всегда фактически аргументированы, что, в свою очередь обуславливает низкий уровень первичной профилактики изменений пародонта и недостаточную медицинскую эффективность лечебных мероприятий у стоматолога, терапевта и гинеколога, стоматологического, психологического статуса.

Ключевые слова: беременность, заболевания пародонта, пародонтопатогены, стоматологический статус, психоэмоциональный статус

\section{MORBIDITY OF PERIODONTAL TISSUE OF PREGNANT WOMEN AND THE MECHANISM OF ITS OCCURRENCE AND DEVELOPMENT (REVIEW OF THE REFERENCES)}

\section{L.I. Ostrovska}

Abstract. The article presents an analysis of the literature regarding the high prevalence and intensity of periodontal diseases of pregnant women and polyetiologicy way of their origin along with the complex development mechanism. But these issues are controversial in nature, are not always reasoned, which, in turn, causes a low level of primary prevention of periodontal changes and lack of medical effectiveness of therapeutic interventions at dentist's, therapist's and gynecologist's, and leads to dental psychological status.

Key words: pregnancy, periodontal diseases, parodontopatogenes, dental health, psycho-emotional status.

Higher State Educational Institution of Ukraine «Ukrainian Medical Stomatological Academy» (Poltava)

Рецензент - доц. О.В. Митченок

С Л.Й. Островська, 2016
Buk. Med. Herald. - 2016. - Vol. 20, № 1 (77). - P. 215-219 